\title{
Multimodal Interaction in a Foreign Language Class at Higher Education Institutions of Ukraine
}

\author{
Viktoriya M. Bilytska ${ }^{1}$, Oksana R. Andriiashyk ${ }^{2}$, Yaroslav V. Tsekhmister ${ }^{3,}$, Olha V. Pavlenko $^{4}$ \& Iryna V. Savka ${ }^{5}$ \\ ${ }^{1}$ Department of Theory, Practice and Translation of German, Faculty of Linguistics, National Technical University of \\ Ukraine "Igor Sikorsky Kyiv Polytechnic Institute", Kyiv, Ukraine \\ ${ }^{2}$ Philology and Natural Sciences Department, Insitute of International Cooperation and Education, National Aviation \\ University, Kyiv, Ukraine \\ ${ }^{3}$ Ukrainian Medical Lyceum, Bogomolets National Medical University Kyiv, Ukraine \\ ${ }^{4}$ Department of English for Engineering \#1, Faculty of Linguistics, National Technical University of Ukraine "Igor \\ Sikorsky Kyiv Polytechnic Institute", Kyiv, Ukraine \\ ${ }^{5}$ Department of Foreign Languages for Humanities, Ivan Franko National University of Lviv, Lviv, Ukraine \\ *Correspondence: Ukrainian Medical Lyceum, Bogomolets National Medical University, 13, T. Shevchenka blvd., \\ Kyiv, 01601, Ukraine. E-mail: y.tsekhmister@gmail.com
}

Received: December 9, 2021

Accepted: January 6, 2022 Online Published: January 17, 2022

doi:10.5430/jct.v11n1p218

URL: https://doi.org/10.5430/jct.v11n1p218

\begin{abstract}
Multimodality is implemented to the modern learning environment in line with trends towards multidisciplinarity. In the current study, multimodal interaction is based on the mutual integration of understanding of multimodality in philological and pedagogical perspectives. The purpose of the article was to analyze and compare the results of learning a foreign language (German) for professional purposes (German for Economists) with an emphasis on multimodal interaction and without it (in a way of traditional language learning with a predominance of classical methods of classroom and extracurricular activities). There were universal scientific and specific methods used: a controlled-type educational experiment; Likert-scale type questionnaire; reliability test: Cronbach's alpha using IBM SPSS Statistics 28.0.0.0; qualitative-quantitative interpretation and contrastive-comparative analysis of the obtained experimental data; statistical-mathematical interpretation of empirical data; comparative analysis; the functional analysis. Respondents of empirical intelligence were students of the Faculty of Management and Marketing, specialty 073 "Management". Averagely in the experimental group, almost all the assessing criteria of the effectiveness of multimodal interaction outreached 4 points. These data were also confirmed by the results of self-reflection-questionnaire. The novelty of the research is in the principle of theoretical substantiation and practical application of the content of multimodal interaction as an umbrella term that integrates the most fundamental concepts of modern pedagogy in general and, in particular, methods of teaching a foreign language.
\end{abstract}

Keywords: foreign language, German language for professional purposes, institutions of higher education (hei), multimodal interaction, mode, students-economists

\section{Introduction}

The study of a foreign language always involves interaction with the text as a basic unit in which can be fully realized units that are relatively autonomous in the non-textual (out-of-discourse) language. The use of authentic texts in foreign language teaching is not a new idea (Coccetta, 2018). Instead, new are the frameworks and models through which philologists-practitioners use different kinds of texts (oral, written; texts of different genres and styles) in language classes. Multimodality as a concept is integrated into the modern learning environment in line with trends towards multidisciplinarity, which means mutual enrichment of disciplines by some notions seemingly diverse and remote, through the exchange of tools, concepts, innovative ideas, etc. (Di Mitri, Schneider, Specht \& Drachsler, 2018). The multifaceted notion of modality, for example, is at the intersection of scientific paradigms such as linguistics, logic, programming, psychology, philosophy, culturology, and even music. In general, modality is characterized as a mode of action or relation to action (MacMillan Dictionary, $n$. d). In the current study, the 
understanding of modality is at least twofold. First, the philological dimension - according to the understanding of modality in the field of linguistics, we interpret it as a set of ways in which people talk about their attitudes, obligations and intentions (MacMillan Dictionary, n. d). Secondly, the methodological and pedagogical dimension, where according to a broader understanding of the term by modern pedagogy, in particular methods of teaching foreign languages, modality is interpreted as an approach focused on mastering a foreign language through the use of different modus (methods of information transfer).

Multimodal interaction is inextricably linked to the communicative situation: this is what A. Gardiner (1879-1963) underlined, emphasizing the incomprehensibility of the general meaning of words outside the situation. Eloquent in this case are examples with homonymous words or even polysemous words, where the situation adds to words the proper content meaning. We may take, for example, German homonymous series grün (green), Grün (das, greens) and grün in the phraseological combination grün hinter den Ohren sein (= in English: to be half-baked / wet behind the ears / unexperienced, too young). Uttered without a proper communicative context, these words will not have correct meaning, will not carry specific communicative information and will not perform their speech function, but, on the contrary, may lead to confusion of meaning, especially if accompanied by incorrect extralingual factors. Moreover, morphologically grün, Grün, grün from the phraseological compound will not actualize their grammatical meaning and other grammatical characteristics without situational or textual context. In contrast, the fact that in a situation of real communication even words-sentences can have a great communicative potential and be informationally and functionally complete in the case of proper situational reinforcement is telling. In addition, multimodality while communicate in a foreign language makes it possible to achieve a communicative goal of the message in the case of imperfectness in terms of language literacy and completeness, as well as in the case of imperfect stylistic arrangement.

In the current study, we aim to analyze and compare the results of learning a foreign language (German) with an emphasis on multimodal interaction and without it - in a way of traditional language learning with the dominance of classical methods of classroom and extracurricular activities.

\section{Literature Review}

Multimodality of foreign language learning closely interacts with today's dominant communicative approach, which corresponds to theories that have been integrated into the paradigm of foreign language learning methodology by Avram Noam Chomsky and Dell Hymes (Kurtes, 2012). Emphasis is placed not only on the importance of linguistic competence, but also on the mastery of a foreign language learner by the contextual, pragmatic, sociocultural and stylistic relevance of the utterance (Atabekova, Lutskovskaia \& Gorbatenko, 2021; O’Dowd \& Dooly, 2020;). Multimodality makes it possible to embrace different approaches to the study of foreign and create the most authentic natural communicative socio-cultural environment (Hoff, 2020; Orsini-Jones \& Lee, 2018). Interaction and mutual integration of the concepts of communicative approach and multimodal learning environment allow the introduction of the concept of multimodal communicative competence (Avgousti, 2018; Coccetta, 2018; Ruiz-Madrid \& Valeiras-Jurado, 2020). Recent works on multimodality are mostly focused on meaning-making beyond the written word (Benjamin, 2019). This thought expands the definition of reading material and allows researchers to consider a wider range of texts (by genres and ways of text representation), especially while taking into consideration specifics of the texts of informational digitalized era (Jung et al., 2019).

In the current study, we follow the definition given by the French linguists Bellik and Teil (1992). Thus, multimodality is the use of different modus to implement the same task. This allows us to assert as an axiom the need to master the practical skills of a person who masters a foreign language, a variety of verbal and nonverbal multimodal means of communication for a specific linguistic and pragmatic purpose. In the perspective of multimodality, the use of the concept of "modus" is inevitable. It is perceived in general as a channel of communication. Synergization of several modus, for example: oral speech, text, facial expressions, gestures, proxemics, visualization (images, videos, etc.) is typical for modern communication in the realities of the digitalized communicative environment of the information age. The key thesis in this case is just the synergy, which is understood, in particular, as compatibility, compatibility and harmony, complementarity of modus. Terminologically, this is defined by the concept of "módusi of multimodal synthesis" (Ye, Chen, Dillig \& Durrett, 2020).

In a multimodal approach, Schmerbeck and Lucht (2017) and Usanova and Schnoor (2021) use the concept of multiliteracies approach, linking it with the active involvement of modern students in interacting with online media, which are explicitly and implicitly transmitted directly or indirectly through visual images., sound effects and audio, in addition to the usual written way of representing the text format of the language. Thus, the essence of the 
multiliteracies approach is to derive learning benefits (achieve intermediate or generalized learning goals) from engaging in the social media learning environment. The pedagogy of multiliteracies can also help to assess the literacy and cultural understanding of German by intermediate learners (Schmerbeck \& Lucht, 2017; Warner \& Dupuy, 2018). Of particular importance for the perspective of the current study is the article of Lindner (2016), which proposes the development of communicative competence of students who study German as a foreign language, in terms of television cooperation and especially for students specializing in business and economics. The advantages of organizing German language teaching on the basis of the multiliteracies approach, which is inevitable under the conditions of multimodal interaction as a way of effective interaction between students and teachers during COVID-19 Pandemic, are also discussed by Cunningham (2021).

The multimodal approach makes it possible to make the difficult process of learning a foreign language more relaxed, introducing an element of entertainment, distraction, and diversity. In addition, the multimodal approach is a source of individualization of learning, the formation of confidence in the individual's tools for using a foreign language. It is an interesting thought about the purpose of expanding the communicative repertoire with enriching it by multimodal expression of attitudes, which are compared with students' simultaneous acquisition of knowledge of metalanguage, which describes the types of meanings and attitudes (Unsworth \& Mills, 2020).

The results of the experiment reflected in the work of Eikel-Pohen (2019) testify in favor of multimodal interaction as a tool of facilitation within process of German teaching. In the study, the multimodality approach was positively assessed as a disability-inclusive language teaching method (the experiment was arranged at the college with students born blind (with increasing hearing loss) as respondents of the study). Similar emphasis is also observed in the work of Barwasser, Lenz and Grünke (2021), but already regarding adolescents with learning and behavioral problems, struggling German as a second language. The positive effect of studying the German language in the perspective of multimodal interaction is evidenced by the work of Benjamin (2019) - based on the example of studying the effect of students' readingings of multimodal literary comics (it were taken texts by Bertolt Brecht with their visual adaptations in comics form by Ulf $\mathrm{K}$ ) .

Based on previous research in the field of multimodal learning Di Mitri et al. (2018) formulates a model of multimodal learning analytics, the main objectives of which are: first, to reflect the use of multimodal data to improve feedback in the context of learning; secondly, the method of combining machine learning with multimodal data; third, the harmonization of terminology used in machine learning and pedagogy. However, in our opinion, it is not necessary to fully equate multimodal foreign language learning with technical teaching aids. In our opinion, the concept of multimodal interaction is much broader. Jewitt Bezemer and O'Halloran (2016) discuss the landscape of sensors and wearable trackers that can be used for learning support to assess the quality of multimodal interaction that integrates tools and is within the research field of functional linguistic, conversational analysis, and social semiotics. Multimodal data for learning: behavior (motor data, physiological data); context (social, situational, environmental) (Di Mitri et al., 2018).

A review of the literature on the topic allows us to conclude that the problem of multimodal interaction is extremely relevant for modern field of methods of teaching a foreign language. The concept of multimodal interaction in this case is an umbrella term that covers many top issues, areas, tools, most discussed among scientists: information and communication technologies (ICT), facilitation, communicative approach and communicative competence, intercultural competence, multiliteracies approach, clip thinking, blended (mixed offline and distance online learning) tools, etc. It is the paradigm of multimodal interaction that allows us to unite and synergize the most current trends in modern pedagogy, the result of which we aim to test in the context of the proposed study.

The analysis of the literature made it possible to identify relevant areas for the development of issues of application of multimodal interaction in modern pedagogy. It also allows to formulate a goal and define the objectives of the current study. Thus, the purpose of the study is to determine the effectiveness of multimodal interaction in foreign language classes (German) in the professional field for students of economic specialties of HEI. The objectives of the study are:

1) to determine the basic principles of multimodal interaction and to investigate the peculiarities of their implementation in non-philological institutions of higher education;

2) to develop a model of multimodal interaction in foreign language classes in accordance with the stages of sensitization, structurization and automation, ensuring the implementation of the above relevant areas of pedagogy;

3) to integrate modern technical means into the system of classroom and extracurricular work to ensure quality educational interaction; 
4) to provide the self-position of the student, his active participation in the learning process, motivation to achieve the best results of educational activities;

5) to develop a model of diagnostics of students' achievements as a result of taking a course of multimodal interaction;

6) systematize, analyze and summarize empirical data;

7) summarize and predict the possibility of further use of multimodal interaction within German lessons.

\section{Methodology}

\subsection{Fundamental Principles and Theoretical Basis of the Research}

The theoretical basis for the organization of the study was the idea of Language for specific purposes (LSP). It is the next one after fundamental for us in the perspective of this study ideas about multimodality and communicative competence as a goal of foreign language learning. LSP is a key notion in the experimental environment of foreign language learning for students of non-philological specialties in the vector of mastering a foreign language (German) for professional purposes. Thus, the dominant goal was not only and not so much purely learning a foreign language to meet ordinary everyday personal needs, but the professional orientation of foreign language competencies (in particular, it is about language variations in a specific subject area; for example, terminology, vocabulary, etc.).

In addition, in the process of educational experiment within the implementation of the principles of multimodal interaction to the types of classroom and extracurricular activities of students, telecollaboration and virtual exchange were tightly incorporated. According to the methodological model of O'Dowd and Dooly (2020) telecollaboration and virtual exchange practice is a pedagogical approach to teaching foreign language, which provides for classes in online projects of intercultural cooperation, i.e. in the process of remote communicative-activity interaction with international partners (especially with native speakers of German).

Thus, our partners in this direction were four representatives of the Ukrainian diaspora abroad (two from Germany, one from Liechtenstein and one from Austria), who work in the countries where they moved to permanent residence after obtaining higher economic education in Ukraine. It is important to note that all four partners work in the field of economics and management. Because of this, the process of communicative interaction with native speaking partners played a particularly important role in the assimilation by the respondents of the experimental group of communicative patterns of multimodal interaction in a professionally oriented perspective.

The three basic modus of multimodality implementation in the study of a foreign language are sensory graphical and multimedia. During the implementation of the multimodal model of interaction within German language classes for professional purposes, we consistently followed three phases of presentation of new material, which are sensitization, structurization and automation (based on the works of Hervé Le Tellier in the interpretation of Krekoten and Baidak (2020)).

\subsection{Sample and Data Collection}

Two groups of respondents from the Faculty of Management and Marketing, specialty 073 "Management" National Technical University of Ukraine "Igor Sikorsky Kyiv Polytechnic Institute", were involved in the study. For maximum reliability of the obtained results, students with approximately equivalent initial levels of German - B1 (Intermediate) - were selected. In the control and experimental groups there were 20 students with an academic success in English at the level of A, B, C according to the Bologna system of assessment (European Credit Transfer System, ECTS). Formally, the experiment lasted 2 months (11 classes, 22 academic hours in class and 45 academic hours in total - including students' compulsory independent work).

In the control group, training took place according to a typical curriculum using traditional methods of teaching. Such types of work as word processing, memorization of new words, grammar and lexico-grammar exercises, concise and detailed translation of texts dominated it. Classroom and extracurricular activities took place without special attention to multimodality and with the involvement of a minimum number of modus.

To organize the experimental multimodal interaction, we chose the Module No I "Deutsch für Studierende der Wirtschaftswissenschaften. Descriptions of the German economy in the context of the global world. Ziele für nachhaltige Entwicklung und Wirtschaft" (students of the parallel control group simultaneously worked on the same Module No I, but the organization of their educational activities was dominated by resources No. 3, 4 from the list below). 
TOP resources that we have involved on a regular basis to organize training in the experimental group:

1) SprachHeld website - https://www.sprachheld.de/business-deutsch/ [web resource];

2) Langenscheidt Sprechtraining Deutsch Für Den Beruf - German Business Communication (German Edition): Übungen Zum Hören und Sprechen by Langenscheidt (2018). Langenscheidt [book].

3) Monolatiy, T. P. German language: a textbook for students of economic specialties. Ivano-Frankivsk: Prykarpattia National University. Univ. V. Stefanika, 2015. 92 p. [book];

4) Vovk L. R. (2003). German for students of economics. A textbook for students of Sh - V courses of economic universities of all specialties. - Ternopil: "Economic Thought" [book];

5) DeStatis.de. Statistisches Bundesamt. Wirtschaftliche Auswirkungen. Statistiken mit Bezug zu COVID-19. https://www.destatis.de/DE/Themen/Querschnitt/Corona/Wirtschaft/kontextinformationen-wirtschaft.html [web resource: text + graphic information + infographics];

6) Zahlen und Fakten. Globalisierung. https://www.bpb.de/nachschlagen/zahlen-und-fakten/globalisierung/ [web resource: text + graphic information + video];

7) Unsere Welt in Zukunft - Wirtschaft: https://www.youtube.com/watch?v=tuqi7q6m4_U [video];

8) Ziele für nachhaltige Entwicklung: https://17ziele.de/ [wer resource: text + graphic information + video].

\subsection{Research Design and Analyzing of Data}

Table 1. Scheme of Assessment of Students' Achievements (common for both groups of respondents)

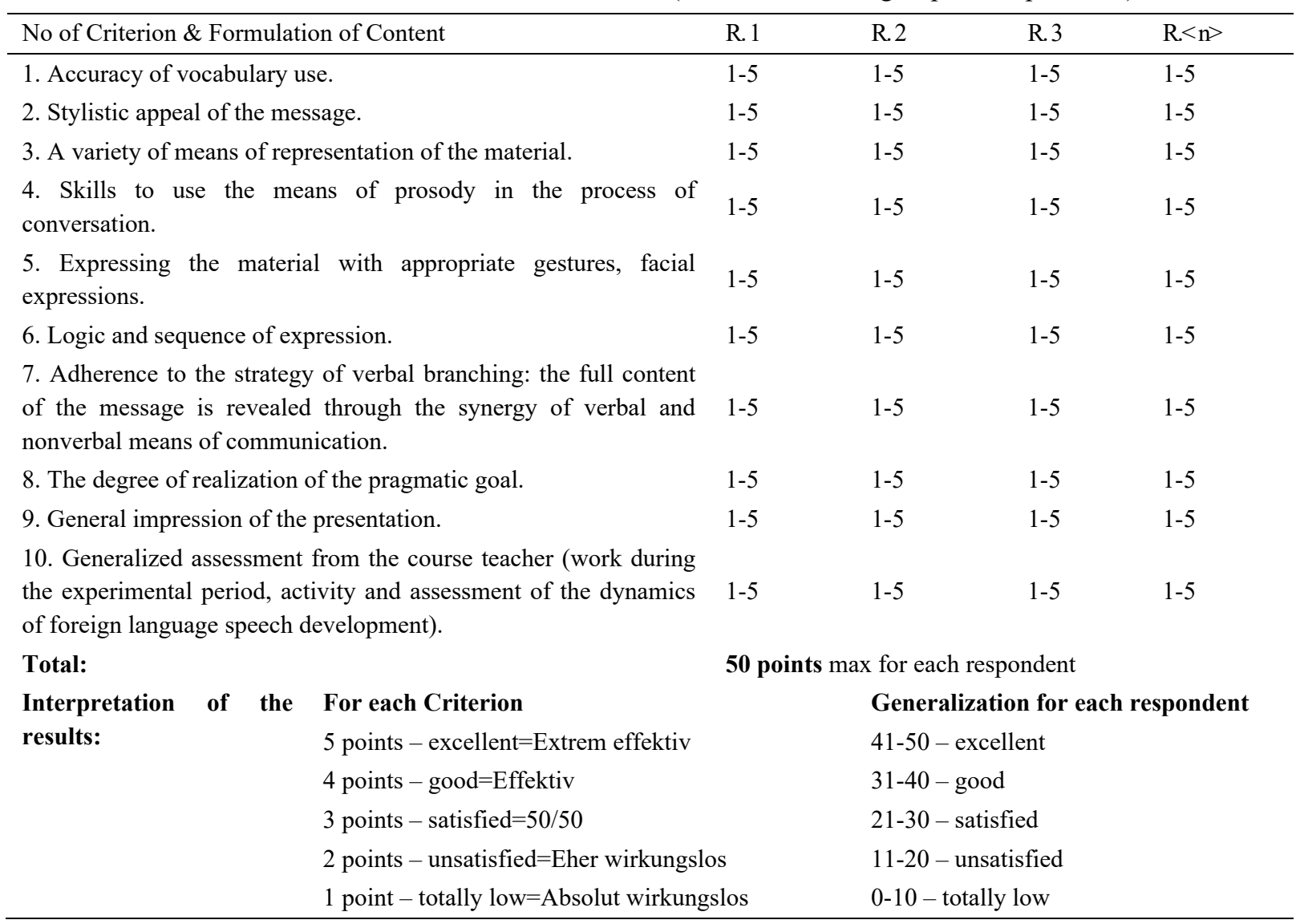

IBM SPSS Statistics 28.0.0.0 and Microsoft Excel 2016 tools were used for Data interpretation.

In general, within framework of the current study there were universal scientific and specific methods used:

- a controlled-type educational experiment;

- $\quad$ Likert-scale type questionnaire; 
- $\quad$ reliability test: Cronbach's alpha using IBM SPSS Statistics 28.0.0.0;

- qualitative-quantitative interpretation and contrastive-comparative analysis of the obtained experimental data;

- statistical-mathematical interpretation of empirical data (using Microsoft Excel tools and graphic interpretation of the data);

- comparative analysis;

- the functional analysis of the experimental data.

Firstly, according to the results of reporting for each student of the experimental and control group was a summary card of the following format (Table 1).

Grades 1-5 were given as a result of collective agreement by a group of independent experts (head of the German language department, 2 invited German teachers from partner universities, 2 invited German speakers: 1 with pedagogical philological education and 1 with economist education). Only criterion 10 was taken exclusively from the opinion of the teacher of the German language course.

Secondly, attitude questionnaire designed by the researcher for the purpose of this study (designed as a Likert-type scale questions - refer Appendix A). In order to verify the reliability of the questionnaire, an analysis was performed according to the method of Cronbach's Alpha (shows the internal consistency of the characteristics describing one object). Data from the results of a questionnaire using Cronbach alpha value proved a reliability coefficient of 0.76 , which is above the 0.70 threshold for acceptable reliability of the questions. It is considered that the Cronbachs Alpha score above 0.7 is interpreted as a sufficient level of reliability of the questionnaire (Table 2).

Table 2. Cronbach's Alpha check Of Attitude Questionnaire

\begin{tabular}{ccc}
\hline & Reliability Statistics & \\
Cronbach's Alpha & N of Items \\
\hline, 757 & 10 \\
\hline
\end{tabular}

\section{Findings / Results}

\subsection{Features of Constructing Multimodal Interaction in the Experimental Group}

Thus, the implementation of the principle of multimodality in the study of the German language followed by the involving different modus to achieve the goal (the study of new concepts by students in a communicative way). The main modus types are:

a) sensory, involving the maximum number of senses (by ear, which allows you to feel the melody of the sound, grasp the nuances of information, visually assess gestures, facial expressions, looks, elements of proxemics, teacher's actions in explaining new material, generalization and consolidation, etc.);

b) graphically (using drawings, pictures, graphs, charts, infographics, etc.);

c) multimedia (combination of audio, video, graphic, text and digital signals, as well as static and moving images and structures).

We believe that the understanding and ability to productively use the concept of the proposed (in the section of the methodology) three phases of presentation of the material is fundamentally important for the organization of high-quality multimodal interaction, especially if we consider it as a tool for facilitation:

- sensitization. Allows to introduce a new concept without explanations by the teacher. During the sensitization phase, the teacher is mostly silent, using graphic teaching material. And students have the opportunity to make assumptions about the content. When the teacher hears the correct statement, he gives a signal and moves on to the next concept. Let's call it a perceptual stage.

- structurization. Conceptualizes the structure in speech and involves the use of, among others, verbal mode. During the second phase, the teacher presents the concept verbally, adding facial expressions and gestures, while the conceptualization of the structure continues. Let's call it a reproductive stage.

- automation. Occurs on the basis of manipulation by the important for memorization forms and techniques. Provides for active communicative involvement of students in work.

Let's call it a productive stage. This is the most active stage associated with imitating the gestures and movements of the teacher, group, pair and individual work. However, it is important to vary the modus in the system of presentation 
of educational material, because the modus affect different students in different ways (in accordance to the dominant types of information perception there are audials, visuals, kinesthetics). It is also important to formulate priority modus for a given academic group, for a given study material, which prove to be the most effective, allowing to achieve the goal most fully in the shortest possible time. In addition, it is important to give students the opportunity to choose the most optimal language operating modus, which will help memorize the material and practice communication skills by the individual predisposition. An appropriate form of work is also to involve students in the diversification of mostly textual material of textbooks and manuals with illustrative components. For example, searching for audiovisual information on the Internet, creating illustrations, wall newspapers, brochures, presentations, shooting videos. All this contributes, as research has shown, to the multimodality of the learning environment, which also stimulates activity, motivation, creativity and communicative emphasis in learning.

Interpretation of this experimental structure based on multimodal interaction and the contrast traditional one is given in Table 3. For clarity of distinction, the multimodal model is presented in comparison with the traditional model of foreign language teaching that dominated the control group,

Table 3. An Example of Explanation of New Material: Comparison of Methods of Multimodal Interaction (experimental group) and Traditional Learning Environment (control group)

\begin{tabular}{|c|c|c|}
\hline $\begin{array}{l}\text { Phases of } \\
\text { presentation }\end{array}$ & Experimental group & Control group \\
\hline 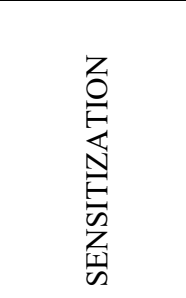 & $\begin{array}{l}\text { Students analyze the graphic material on the topic "Sustainable } \\
\text { Development" (printed infographics from https://17ziele.de/, for a } \\
\text { sample - Appendix B), green markers mark familiar words, red - } \\
\text { unfamiliar. The text is read twice in different tonalities (recorded } \\
\text { by a native German speaker). Assumptions are made about the } \\
\text { meaning of new words. The teacher does not participate in the } \\
\text { explanation. }\end{array}$ & $\begin{array}{l}\text { The teacher reads the text twice in } \\
\text { equal tone to explain the goals of } \\
\text { sustainable development. Students } \\
\text { perceive the text by ear, then } \\
\text { receive printouts of the text, from } \\
\text { which they write in two columns } \\
\text { familiar and unfamiliar words. }\end{array}$ \\
\hline 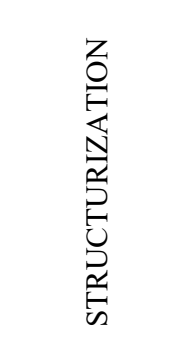 & $\begin{array}{l}\text { The teacher explains the material using prosidika means (system of } \\
\text { phonetic means: accents, meliza, timbre, melody, discontinuity, } \\
\text { rhythm, intonation, volume, pause, tonality, force stress, duration), } \\
\text { gestures and facial expressions, students repeat in different } \\
\text { tonalities. View and further analyze videos on the topic. Working } \\
\text { with deadlines on colored cards. Learning new words with cards. } \\
\text { Creating illustrations (comics) that would convey the meaning of } \\
\text { new words (individual and group work). }\end{array}$ & $\begin{array}{l}\text { Work with words-terms and } \\
\text { definitions: independent } \\
\text { elaboration, lexical-grammatical } \\
\text { exercise on word substitution. } \\
\text { Grammatical analysis of the text. } \\
\text { Chain reading and translation. }\end{array}$ \\
\hline \multirow{4}{*}{ 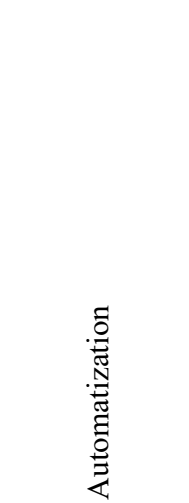 } & $\begin{array}{l}\text { Work in pairs: "Ask emotionally." } \\
\text { Role-playing game "Guess who I am or what I am?" (task is to } \\
\text { portray / act a new word without naming it). } \\
\text { Development of new lexical material in the process of discussion } \\
\text { with native speakers (with the involvement of the Google Meet } \\
\text { platform). }\end{array}$ & \multirow[t]{4}{*}{$\begin{array}{l}\text { Vocabulary control (oral } \\
\text { examination, vocabulary } \\
\text { dictation). Answers to questions } \\
\text { to the text (oral and written). } \\
\text { Compiling a block of questions on } \\
\text { the topic. Writing reports on the } \\
\text { topic. }\end{array}$} \\
\hline & Problematic discussion of issues in the group. Discussion. & \\
\hline & Essay-self-reflection on the results of each week of the experiment. & \\
\hline & $\begin{array}{l}\text { Visiting production that works on the basis of eco-economy } \\
\text { (ecological economy). In German, accompanied by a hired guide. }\end{array}$ & \\
\hline
\end{tabular}

4.2 Indicators of the Effectiveness of Multimodal Interaction in German Language Classes According to the Developed Diagnostic Model and Questionnaire

The grades provided by the expert group and the teacher of the German language in the professional field course for students of economic specialties of the experimental group are given in Table 4. 
Table 4. Assessment of Students’ Achievements (Experimental Group)

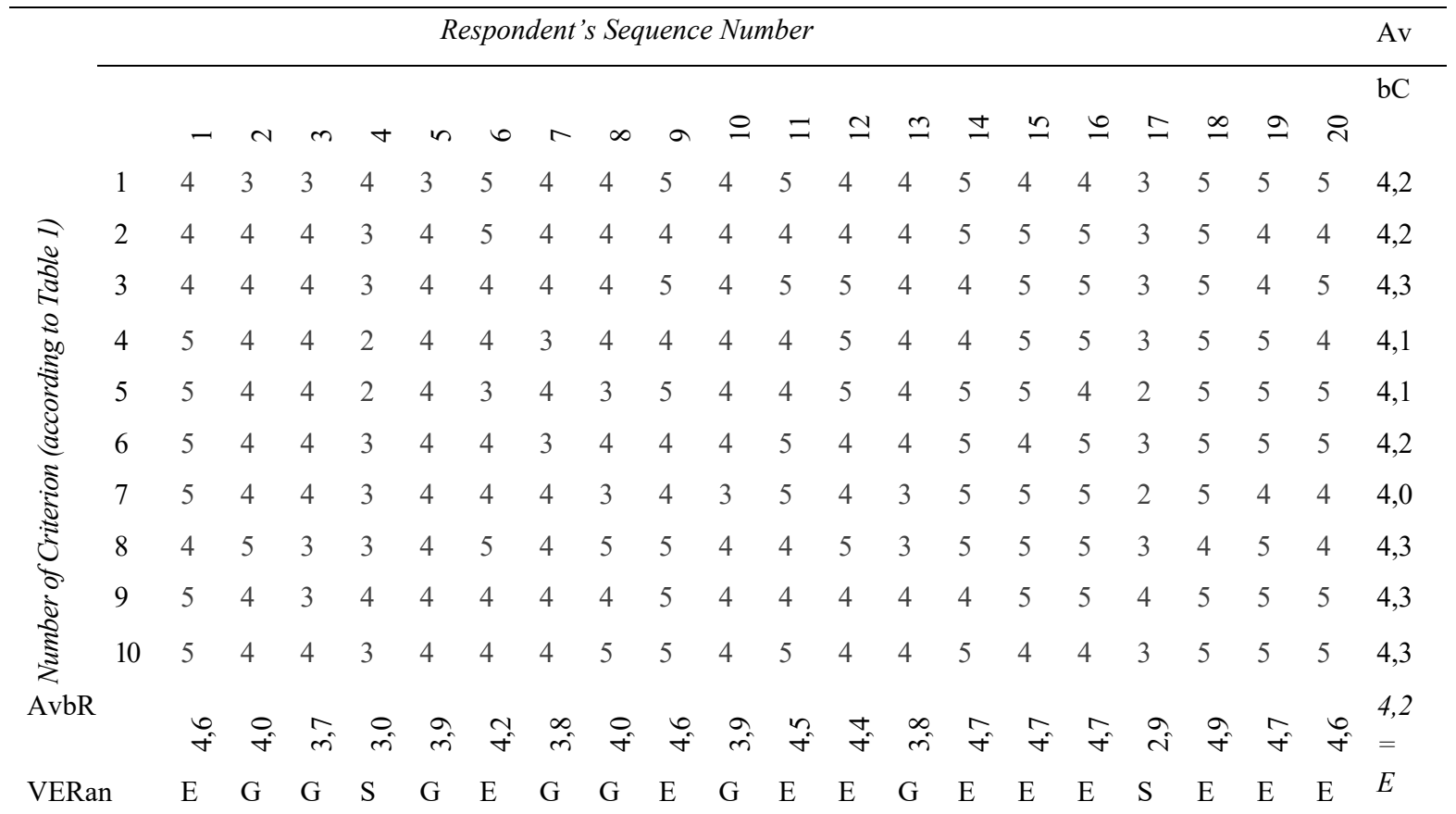

**Scale for interpretation (taking into account decimal fractions in the case of averaging individual results within a group or subtracting an individual average assessment of the effectiveness of the model of multimodal interaction by each individual student):

4.1-5.0 points - excellent (Extremely effective); 3.1-4.0 points - good (Effective); 2.1-3.0 points - satisfied (50/50); 1.1-2.0 points - unsatisfied (Rather ineffective); 1.0 point - totally low (Absolutely ineffective).

! This principle of assessment and interpretation is also applicable for the next Tables within this study.

Note: $\mathrm{AvbC}=$ averagely by criterion; AvbR = averagely by respondent; VERan = verbal evaluation range; $\mathrm{E}=$ excellent; $\mathrm{G}=$ good; $\mathrm{S}=$ satisfied; $\mathrm{US}=$ =unsatisfied; $\mathrm{TL}=$ totally low.

As is obvious, averagely in the experimental group for almost all the selected criteria of assessing the effectiveness of multimodal interaction it is reached a level of more than 4 points (for $90 \%$ of the criteria). I.e. the result was concentrated within the verbal evaluation range "Excellent" ("Extremely effective"). However, the major difficulties was with managing to meet the criterion "Adherence to the strategy of verbal branching: the full content of the message is revealed through the synergy of verbal and nonverbal means of communication." Here, the average score was 4.0 points (within "Good"). It is also telling that according to this criterion, the level of four respondents focused on the mark "Satisfied" and even one on the level "Unsatisfied" on this point. Thus, maintaining the synergy of modus within the strategy of verbal branching can be considered the most difficult aspect of multimodal interaction when learning a foreign (German) language.

The result of the assessment of the achievements of students of the control group in the ability to use different modus of learning a foreign language and reproducing them in productive speech is presented in Table 5. 
Table 5. Assessment of Students' Achievements (Control Group)

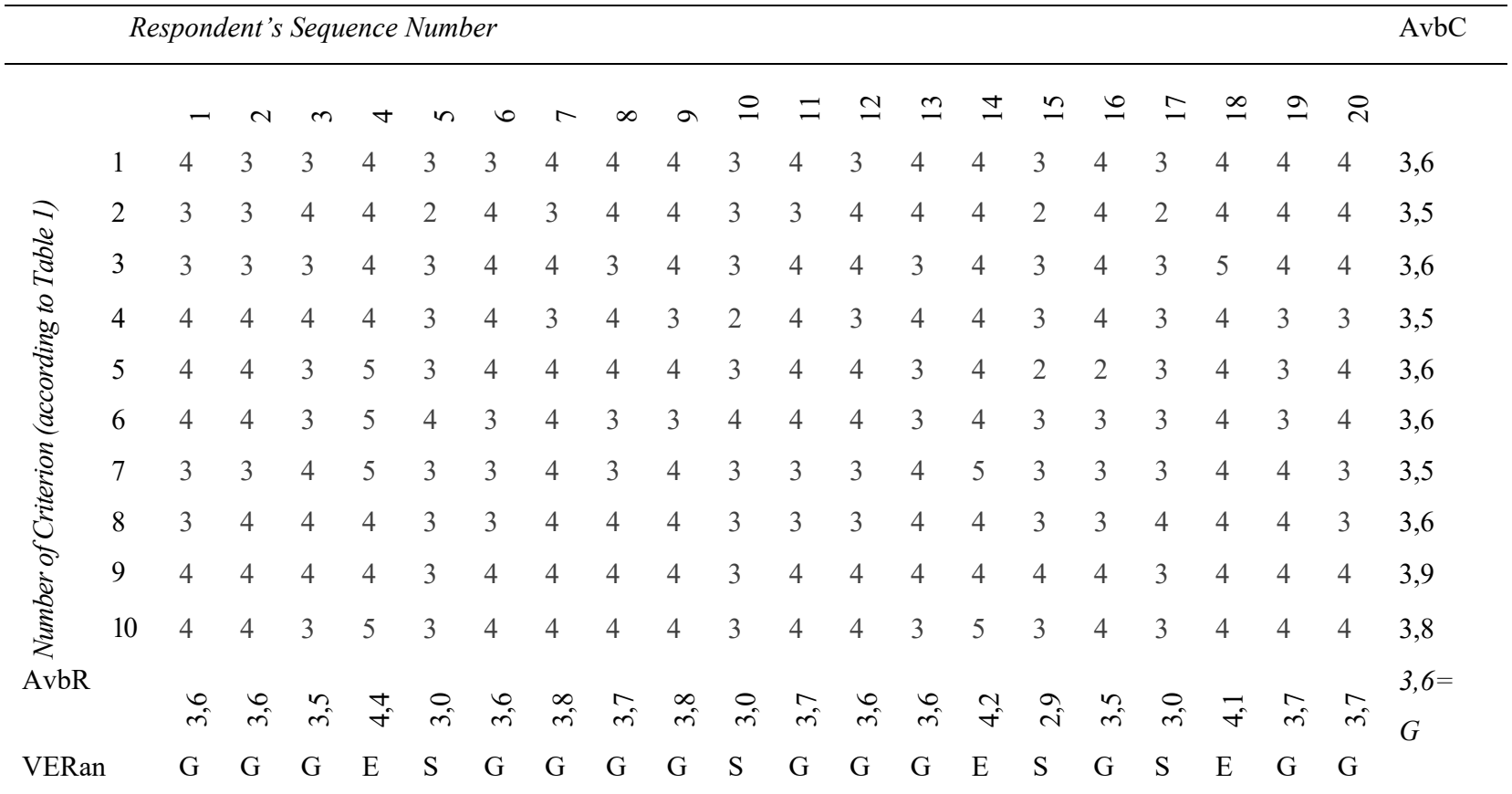

Note: $\mathrm{AvbC}=$ averagely by criterion; $\mathrm{AvbR}=$ averagely by respondent; VERan $=$ verbal evaluation range; $\mathrm{E}=$ excellent; $\mathrm{G}=$ good; $\mathrm{S}=$ satisfied; $\mathrm{US}=$ unsatisfied; $\mathrm{TL}=$ totally low.

As for the average level of achievements according to the selected criteria for assessing compliance with the principles of multimodal interaction in the control group (where no training activities were organized in accordance with the principles of multimodal interaction), all ten points achieved more than 3 points (for $100 \%$ criteria). within the verbal evaluation range Excellent (Good). However, much more informative and even contrasting for such optimistic results is the assessment of an individual respondent of the control group.

By summarizing and comparing the identified levels of effectiveness of both groups of respondents, we obtain Table 6.

Table 6. Comparison of the Results of Experimental and Control Group

\begin{tabular}{lllll}
\hline \multirow{2}{*}{ Verbal Evaluation Range } & \multicolumn{4}{c}{ Number of Students } \\
\cline { 2 - 5 } & \multicolumn{2}{c}{ Experimental Group } & \multicolumn{3}{c}{ Control Group } \\
\cline { 2 - 5 } & No & $60,0 \%$ & 3 & $\%$ \\
\hline $4.1-5.0$ points - Excellent & 12 & $35,0 \%$ & 13 & $15 \%$ \\
$3.1-4.0$ points - Good & 7 & $5,0 \%$ & 4 & $65 \%$ \\
$2.1-3.0$ points - Satisfied & 1 & 0 & 0 & $20 \%$ \\
$1.1-2.0$ points - Unsatisfied & 0 & 0 & 0 & 0 \\
1.0 point - Totally Low & 0 & & & 0 \\
\hline
\end{tabular}

The results of the questionnaire for the individual determination of the effectiveness of multimodal interaction during the study of the German language by students of the experimental group are presented in Table 7. 
Table 7. The Results of Self-Reflection-Questionnaire Held for Students of the Experimental Group to Assess the Effectiveness of Multimodal Interaction

\begin{tabular}{lccccccccccc}
\hline RNo & Q1 & Q2 & Q3 & Q4 & Q5 & Q6 & Q7 & Q8 & Q9 & Q10 & Avg by R \\
\hline R1 & 4 & 5 & 5 & 4 & 5 & 3 & 4 & 3 & 4 & 5 & 4,2 \\
R2 & 3 & 4 & 3 & 3 & 5 & 5 & 3 & 4 & 4 & 4 & 3,8 \\
R3 & 5 & 4 & 4 & 4 & 3 & 5 & 4 & 5 & 4 & 5 & 4,3 \\
R4 & 5 & 4 & 4 & 5 & 4 & 4 & 4 & 3 & 5 & 5 & 4,3 \\
R5 & 5 & 5 & 5 & 5 & 5 & 4 & 4 & 5 & 5 & 5 & 4,8 \\
R6 & 4 & 4 & 5 & 5 & 5 & 4 & 3 & 4 & 5 & 5 & 4,4 \\
R7 & 5 & 5 & 4 & 3 & 5 & 5 & 5 & 3 & 3 & 5 & 4,3 \\
R8 & 4 & 4 & 2 & 3 & 2 & 3 & 3 & 4 & 3 & 2 & 3 \\
R9 & 4 & 5 & 4 & 5 & 4 & 4 & 5 & 5 & 4 & 4 & 4,4 \\
R10 & 5 & 5 & 5 & 4 & 5 & 5 & 5 & 4 & 5 & 5 & 4,8 \\
R11 & 4 & 4 & 4 & 3 & 3 & 4 & 4 & 4 & 4 & 3 & 3,7 \\
R12 & 5 & 5 & 5 & 5 & 5 & 4 & 4 & 4 & 5 & 5 & 4,7 \\
R13 & 4 & 4 & 4 & 4 & 4 & 5 & 4 & 3 & 4 & 5 & 4,1 \\
R14 & 5 & 4 & 3 & 5 & 4 & 3 & 5 & 4 & 4 & 5 & 4,2 \\
R15 & 4 & 5 & 4 & 4 & 3 & 4 & 4 & 5 & 4 & 4 & 4,1 \\
R16 & 5 & 5 & 5 & 5 & 4 & 4 & 4 & 4 & 5 & 4 & 4,5 \\
R17 & 5 & 5 & 5 & 4 & 5 & 5 & 4 & 4 & 4 & 5 & 4,6 \\
R18 & 4 & 5 & 5 & 5 & 3 & 3 & 3 & 4 & 4 & 5 & 4,1 \\
R19 & 4 & 4 & 5 & 4 & 4 & 2 & 4 & 3 & 4 & 5 & 3,9 \\
R20 & 4 & 5 & 3 & 4 & 4 & 4 & 2 & 3 & 5 & 4 & 3,8 \\
AvgbyQ & 4,4 & 4,6 & 4,2 & 4,2 & 4,1 & 4 & 3,9 & 3,9 & 4,3 & 4,5 & 4,2 \\
\hline
\end{tabular}

Note: * $\mathrm{RNo}=$ respondent's sequence number; $\mathrm{R}=$ respondent; $\mathrm{Q}(\mathrm{n})=$ question number (in accordance with Questionnaire of Appendix A); Avg by $\mathrm{Q}=$ Average point by question; Avg by $\mathrm{R}=$ Average point by respondent.

Thus, the results of the survey showed that the overall level of effectiveness of multimodal interaction in foreign language classes (according to the subjective individual assessment of the students of the experimental group) was averaged within the mark "Excellent", but at the lowest levels of this range. That is, there is still a lot of possibilities for improvement. After all, pedagogical interaction provides maximum comfort for both subjects of the pedagogical process (teacher / student) and the highest efficiency for the student. According to the criteria, data were obtained that the work on point Q2 was organized most effectively ("Has the format of multimodal interaction made your study of the new material easier?"). This very important indicator confirms the predicted facilitating function of multimodal foreign language learning. Instead, Q7 ("How well were the different ways of perceiving the new material combined?") and Q8 ("How did the experiment affect your activity and initiative while learning German?") proved to be the weakest. However, even on these questions, the dynamics is very positive and averaged at the level of "Good".

Regarding the overall assessment of individual respondents on the proposed ten questions, only one of the respondents (5\%) occurred at the level of "Satisfied". In addition, four respondents gave an average assessment at the level of "Good" (20\%). All others are concentrated in the range of "Excellent", nowhere, however, without reaching the maximum mark of 5.0. In other words, each of the respondents tried to critically evaluate different aspects of multimodal interaction, noticing both very positive moments and those aspects that can be improved. In general, this is another guarantee of plausibility, reliability of the sample. Consequently, the reliability of the overall positive assessment of the experiment on multimodal interaction in German language classes for professional purposes. 
It is also informative to compare the results found in the experimental group according to the two evaluation methods (Table 8). When comparing the results, taking into account a number of factors and features of objective assessment (by experts) and subjective assessment-self-reflection (by students), we took an error of $\leq 0.9$ points, or $\leq 18 \%$, as the basis for recognizing compliance).

Table 8. Comparison of the Results Found in the Experimental Group by Two Evaluation Methods

\begin{tabular}{lllll}
\hline RNo & Evaluation by experts & Evaluation by students & Deviation in $\%$ & $\begin{array}{l}\text { Correspondence between the } \\
\text { two methods? }\end{array}$ \\
\hline 1 & 4,6 & 4,2 & $-9 \%$ & There is a match. \\
2 & 4 & 3,8 & $-5 \%$ & There is a match. \\
3 & 3,7 & 4,3 & $16 \%$ & There is a match. \\
4 & 3 & 4,3 & $43 \%$ & There is no match. \\
5 & 3,9 & 4,8 & $23 \%$ & There is no match. \\
6 & 4,2 & 4,4 & $5 \%$ & There is a match. \\
7 & 3,8 & 4,3 & $13 \%$ & There is a match. \\
8 & 4 & 3 & $-25 \%$ & There is no match. \\
9 & 4,6 & 4,4 & $-4 \%$ & There is a match. \\
10 & 3,9 & 4,8 & $23 \%$ & There is no match. \\
11 & 4,5 & 3,7 & $-18 \%$ & There is a match. \\
12 & 4,4 & 4,7 & $7 \%$ & There is a match. \\
13 & 3,8 & 4,1 & $8 \%$ & There is a match. \\
14 & 4,7 & 4,2 & $-11 \%$ & There is a match. \\
15 & 4,7 & 4,1 & $-13 \%$ & There is a match. \\
16 & 4,7 & 4,5 & $-4 \%$ & There is a match. \\
17 & 2,9 & 4,6 & $59 \%$ & There is no match. \\
18 & 4,9 & 4,1 & $-16 \%$ & There is a match. \\
19 & 4,7 & 3,9 & $-17 \%$ & There is a match. \\
20 & 4,6 & 3,8 & $-17 \%$ & There is a match. \\
AvbR & 4,2 & 4,2 & $0 \%$ & There is an absolute match. \\
\hline
\end{tabular}

There is no match for five respondents. As can be seen from the Table 8 , the negative deviation dominates. It will be recalled that according to the second indicator, each respondent subjectively assessed the effectiveness of the German language course in terms of multimodal interaction. It was against him that the result of expert opinion was compared. The predominance of negative deviation in this case may indicate: a) lack of explanation to students what expectations are placed on the experimental course, as a result of which they underestimated the self-esteem of success; b) excessive demands of the teacher, which caused the low opinion of students about the effectiveness of their work; c) special preparation of students for the final reporting lesson based on the results of the experiment, as a result of which the expert opinion could slightly exceed the real state of success of multimodal learning. In the two respondents where the discrepancy is most significant (59\% and $43 \%$ ), the deviation is positive rather than negative. That is, these students, on the contrary, significantly overestimated their performance and / or they had reasons why they presented themselves very poorly in the final report. However, for the majority of respondents we see similarities in the conclusions of experts and the subjective assessment of the experiment by respondents. In addition, most importantly, the average generalized assessment within the whole group coincided exactly. This again confirms the idea of the positive effects of the experiment and the effectiveness of the developed diagnostic methods. 


\section{Discussion}

In formulating the principles of the developed course of studying the German language on the basis of multimodal interaction, there was a rethinking of the concept of communicative competence in the vector of multimodal perspective (Coccetta, 2018). This provided a kind of goal of developing metalanguage by students, which would allow the ability to understand, use, produce independently texts (oral, written), in which semiotic resources, synergizing, unfold in specific texts, also allowing students to express their ideas in the context of discourses, situational and sociocultural markers (Hoff, 2020).

The work towards the implementation of multimodal interaction each time involved three stages: 1) direct multimodal interaction within the classroom employment; 2) analysis of verbal and nonverbal markers of multimodal interaction, assessment of their significance, role in achieving the pragmatic goal of the communicative act; 3 ) reflection on the personal level of multimodal interaction during communication in a foreign language, assessment of one's ability to interact in a multimodal key in a foreign language and, for comparison, in the native language, setting priorities for improvement, etc. (usually in essay or oral presentation). Students, analyzing text (oral, written), exchanging remarks during communicative interaction in online and offline format, used analytical tools that guided them in the study of a complex array of semiotic resources that contribute to the meaning of expression (Kapsargina, Shmeleva \& Olentsova, 2020). Thus, the processes of material memorization were intensified (Lawless, 2019). It is expedient to implement the longest possible stay of students in a multimodal foreign language environment in foreign language classes for professional purposes (German for Economists). This contributes to the development of multimodal communicative competence, which undoubtedly has an important metacommunicative component, as it encourages, on the one hand, the activation of thought processes, and on the other hand, automation processes (Freyn, 2017; Jung et al., 2019; Krekoten \& Baidak, 2020).

Multimodal learning, in our opinion, corresponds to a special and very important mission of a teacher of a non-linguistic educational institution: first, to teach students to communicate not only with words but also with other nonverbal means, such as gestures, intonation, head movements, facial expressions, etc.; second, to facilitate the perception of any information in a foreign language by schematization or simplification. This view coincides with the dominant ideas of a number of scholars and educators-practitioners, who on a regular basis interact with the problem of formulating a range of foreign language competencies of students within the study of a foreign language course in a professional field.

The system of multimodal interaction during the experiment was consistently built on the principles that a person learning a foreign language should always recognize the input data from different modalities (Ye et al., 2020), combining them according to time and context constraints to enable their interpretation and fixation in memory (Barwasser, Lenz \& Grünke, 2021; Floyd \& Castek, 2021; Hoff, 2020). From the perspective of the experiment, the tendency to use text creation (perception of others and production of one's own texts), also called verbal branching strategy (Červenková, 2018; Wallace, 2021), was actively used, when the full meaning of the text is revealed through illustrative components. Equally, important tools for achieving the result were the predominant adherence to the three phases of presentation of new material, namely: sensibilization, structuring and automation (Krekoten \& Baidak, 2020) with appropriate organizational-procedural and instrumental-methodological content, as shown in results' paragraph.

Discussing the positive results of the experiment, we also emphasize the facilitator option of multimodal interaction, which is confirmed not only by expert assessments, but also by positive responses of students of the experimental group. By the item 2 of the questionnaire ("Has the format of multimodal interaction made your study of the new material easier?") they evaluated the multimodal technique at 4.6 points, which corresponds to the level of "Extremely Effective". This is exceptionally important for teaching non-philological students, as research confirms that the top barriers to learning a foreign language are frustrating because learning a language can be very difficult. In addition, non-philological students usually lack motivation (Ava, 2021; DTS Language Services, 2021; Romadloni \& Mantasiah, 2017). As it can be concluded, multimedia learning in this case is a real find.

\section{Conclusion}

Thus, the use of multimodality helps to increase efficiency and accelerate the process of learning a foreign language. The use of multimodal objects as authentic materials during practical classes arouses interest and encourages communication. In learning a foreign language, it is important to use everything that is inherent in real human communication and interaction. Of course, the main thing is the verbal content of the lesson, but we should not underestimate even such, at least, less significant aspects of pedagogical and generally communicative interaction as 
looks, gestures, facial expressions, emotional expressions, tonality and even the posture of communicators. All this is a source of meta-information, which allows filling the gaps in communicative knowledge and skills for a person who does not speak a foreign language fluently. Nevertheless, the tools of multimodal interaction are important at any level of language proficiency.

The presented article contributes to the study of a multimodal approach to teaching a foreign language, namely a foreign language in the professional field (German) to non-philological specialties of higher education. In particular, the proposed model of learning, the effectiveness of which is tested in the process of experimental research by the author's diagnostic methods, implements communicative interaction based on different modus, forming not only practical skills of multimodal interaction in a foreign language in professional and everyday communication, but also learning analytical bases analysis of the communicative situation.

One of the most important innovations of the current study is the principle of theoretical justification and practical application of the content of multimodal interaction as an umbrella term that integrates the most basic concepts of modern pedagogy in general and, in particular, methods of teaching a foreign language. This idea has been consistently covered and implemented throughout all sections of the study.

\section{Recommendations}

The issue of multimodal interaction in a foreign language class requires further research, especially in non-linguistic institutions of higher education. It is important to consider a multimodal approach to creating new textbooks and manuals, as students' knowledge requirements are growing. We believe that in the context of multimodal interaction, the very concept of a textbook or textbook is leveled and should be replaced by the concept of educational complex. Moreover, in the case of learning a foreign language for professional purposes it should be professionally oriented.

Teachers face more and more new tasks and challenges (for example, distance and blended learning, which has become the only method of pedagogical interaction in a coronavirus pandemic). It is possible to answer them only on the basis of the most modern scientific researches. Researchers who wish to continue studying the potential and various subtleties of multimodal interaction while studying a foreign language, in particular German, are advised to adhere to our proposed principle of semantic expansion of the concept of multimodality.

\section{Limitations}

The limitations of the study can be considered a relatively small sample size $(n=20)$ in both control and experimental groups. The proposed diagnostic model cannot be considered sufficiently justified and proven effective to assess the effectiveness of multimodal interaction. Therefore, by analogy with the current, it is necessary to organize similar studies that would attract a large number of respondents and go beyond the scope of application only for students of economic specialties. Instead, students of various non-philological fields of study and, possibly, different educational and qualification levels of university training were tested. In addition, the time of the experiment (in our case it has 2 months duration), we assume, can serve as a significant limitation for categorical judgments about the degree of positive impact on the educational achievements of students of multimodal interaction for a wider or narrower period. In our study, we included in the sample students with the level of academic achievement in a foreign language at the level of A, B, C, as well as the level of knowledge of the German language B1 (Intermediate). It is important to investigate how performance indicators will vary if these limitations are abandoned when organizing subsequent empirical research.

\section{References}

Atabekova, A., Lutskovskaia, L., \& Gorbatenko, R. (2021). Developing multiliteracy skills and pragmatic communication awareness of university students learning a foreign language (English) for specific purposes. Thinking Skills and Creativity, 42, 100956. https://doi.org/10.1016/j.tsc.2021.100956

Ava, A. (2021, April, 15). The challenges of learning a new language. Retrieved from https://www.marstranslation.com/blog/the-challenges-of-learning-a-new-language

Avgousti, M. I. (2018). Intercultural communicative competence and online exchanges: A systematic review. Computer Assisted Language Learning, 31(8), 819-853. https://doi.org/10.1080/09588221.2018.1455713 
Barwasser, A., Lenz, B., \& Grünke, M. (2021). A multimodal storytelling intervention for improving the reading and vocabulary skills of struggling German-as-a-second-language adolescents with learning and behavioral problems. Insights into Learning Disabilities, 18(1), 29-51.

Bellik Y. D., \& Teil, D. (1992). Définitions terminologiques pour la communication multimodale [Terminological definitions for multimodal communication]. https://perso.limsi.fr/bellik/publications/1992_IHM_1.pdf

Benjamin, J. D. (2019). Reading the German graphic novel: understanding learners' readings of multimodal literary comics (Doctoral dissertation. University of Texas at Austin, Austin, TX). http://dx.doi.org/10.26153/tsw/2991

Červenková, T. (2018). Verbal communication strategies in English as a foreign language (Master's thesis. University Karlovy/Charles University, Prague, Czech Republic) Retrieved from https://dspace.cuni.cz/handle/20.500.11956/101793

Coccetta, F. (2018). Developing university students' multimodal communicative competence: Field research into multimodal text studies in English. System, 77, 19-27. https://doi.org/10.1016/j.system.2018.01.004

Cunningham, D. J. (2021). Adapting an undergraduate multiliteracies german curriculum for online instruction during the COVID-19 pandemic. Íkala, 26(3), 749-765.https://doi.org/10.17533/udea.ikala.v26n3a15

Di Mitri, D., Schneider, J., Specht, M., \& Drachsler, H. (2018). From signals to knowledge: A conceptual model for multimodal learning analytics. Journal of Computer Assisted Learning, 34, 338-349. https://doi.org/10.1111/jcal.12288

DTS Language Services. (2021). 5 big obstacles to learning a new language. Retrieved from https://www.dtstranslates.com/globalcommunicationblog/5-obstacles-learning-new-language/

Eikel-Pohen, M. (2019). Assessing disability-inclusive language teaching methods with multimodality and universal design principles. Die Unterrichtspraxis/Teaching German, 52(1), 1-13. https://doi.org/10.1111/tger.12081

Floyd, R., \& Castek, J. (2021). Academic, emotional, and social growth in the second language classroom: a study of multimodality. In multifaceted strategies for social-emotional learning and whole learner education (pp. 163-188). Hershey, PA: IGI global.

Freyn, A. L. (2017). Effects of a multimodal approach on esl/efl university students' attitudes towards poetry. Journal of Education and Practice, 8(8), 80-83.

Hoff, H. E. (2020). The evolution of intercultural communicative competence: conceptualizations, critiques and consequences for 21st century classroom practice. Intercultural Communication Education, 3(2), 55-74.

Jewitt, C., Bezemer, J., \& O'Halloran, K. (2016). Introducing multimodality. London, UK; New York, NY: Routledge.

Jung, Y., Kim, Y., Lee, H., Cathey, R., Carver, J., \& Skalicky, S. (2019). Learner perception of multimodal synchronous computer-mediated communication in foreign language classrooms. Language Teaching Research, 23(3), 287-309. https://doi.org/10.1177\%2F1362168817731910

Kapsargina, S. A., Shmeleva, Z. N., \& Olentsova, J. A. (2020). Innovative methods of working with the text in the process of teaching a foreign language in a non-linguistic university. Advances in Economics, Business and Management Research, 128, 545. https://doi.org/10.2991/aebmr.k.200312.077

Krekoten, O. V., \& Baidak, L. I. (2020). Multimodal approach to work with authentic resources in foreign language classes. Innovative Pedagogy: Scientific Journal, 20(2), 56-62. https://doi.org/10.32843/2663-6085-2020-20-2-11

Kurtes, S. (2012). Key competences in foreign language learning: Historical perspectives and theoretical frameworks. In M. Eisenmann, \& T. Summer (Eds.), Basic issues in EFL teaching and learning (pp. 43-54). Heidelberg, Germany: Universitätsverlag Winter.

Lawless, C. (2019, October 24). Multimodal learning: engaging your learner's senses. Retrieved from $\mathrm{https}$ ://www.learnupon.com/blog/multimodal-learning/

Lindner, R. (2016). Developing communicative competence in global virtual teams: A multiliteracies approach to telecollaboration for students of business and economics. CASALC Review, 1(1), 144-156.14.

$\begin{array}{llllll}\text { MacMillan } & \text { Dictionary. } & \text { (n. } & \text { d). } & \text { Modality. } & \text { Retrieved }\end{array}$ https://www.macmillandictionary.com/dictionary/british/modality 
O’Dowd, R., \& Dooly, M. (2020). Intercultural communicative competence development through telecollaboration and virtual exchange. In J. Jackson (Ed.), The Routledge handbook of language and intercultural communication (pp. 361-375). London, UK; New York, NY: Routledge.

Orsini-Jones, M., \& Lee, F. (2018). Intercultural communicative competence (ICC) revisited. In Intercultural communicative competence for global citizenship (pp. 7-23). London, UK: Palgrave Macmillan. https://doi.org/10.1057/978-1-137-58103-7_2

Romadloni, A., \& Mantasiah, R. (2017). Intercultural approach in foreign language learning to improve students' motivation. The Asian EFL Journal, 98, 61-73.

Ruiz-Madrid, N., \& Valeiras-Jurado, J. (2020). Developing multimodal communicative competence in emerging academic and professional genres. International Journal of English Studies, 20(1), 27-50. https://doi.org/10.6018/ijes.401481

Schmerbeck, N., \& Lucht, F. (2017). Creating meaning through multimodality: Multiliteracies assessment and photo projects for online portfolios. Die Unterrichtspraxis/Teaching German, 50(1), 32-44. https://doi.org/10.1111/tger.12020

Unsworth, L., \& Mills, K. A. (2020). English language teaching of attitude and emotion in digital multimodal composition. Journal of Second Language Writing, 47, 100712. https://doi.org/10.1016/j.jslw.2020.100712

Usanova, I., \& Schnoor, B. (2021). Exploring multiliteracies in multilingual students: Profiles of multilingual writing skills. Bilingual Research Journal, 1, 1-18. https://doi.org/10.1080/15235882.2021.1890649

Wallace, K. M. (2021). Branching out: establishing a global communication strategy for a foreign branch Campus. 2nd World Conference on Teaching and Education. 19-21 February. Vienna, Austria. Retrieved from https://www.dpublication.com/wp-content/uploads/2021/01/06-334.pdf

Warner, C., \& Dupuy, B. (2018). Moving toward multiliteracies in foreign language teaching: Past and present perspectives... and beyond. Foreign Language Annals, 51(1), 116-128. https://doi.org/10.1111/tger.12020

Ye, X., Chen, Q., Dillig, I., \& Durrett, G. (2020). Benchmarking multimodal regex synthesis with complex structures. In Proceedings of the $58^{\text {th }}$ Annual Meeting of the Association for Computational Linguistics, ACL 2020, Online, July 5-10, 2020, pp. 6081-6094. Retrieved from https://aclanthology.org/2020.acl-main.541/ 


\section{Appendix A}

FRAGEBOGEN zur individuellen Ermittlung der Wirksamkeit multimodaler Interaktion während des Studiums der deutschen Sprache durch Studierende der Experimentalgruppe

\begin{tabular}{|c|c|c|c|c|c|c|}
\hline No & Fragenformulierung & Antwortv & nten nach & ert-Ska & & \\
\hline & & $\begin{array}{l}\text { Extrem } \\
\text { effektiv }\end{array}$ & Effektiv & $50 / 50$ & $\begin{array}{l}\text { Eher } \\
\text { wirkungslos }\end{array}$ & $\begin{array}{l}\text { Absolut } \\
\text { wirkungslos }\end{array}$ \\
\hline 1 & $\begin{array}{lll}\text { Wie beurteilen } & \text { Sie } & \text { im } \\
\text { Allgemeinen } & & \text { die } \\
\text { Wirksamkeit } & & \text { des } \\
\text { Experiments für } & \text { sich } \\
\text { persönlich? } & & \end{array}$ & & & & & \\
\hline 2 & $\begin{array}{l}\text { Hat das Format der } \\
\text { multimodalen Interaktion } \\
\text { Ihr Studium des neuen } \\
\text { Materials erleichtert? }\end{array}$ & & & & & \\
\hline 3 & $\begin{array}{l}\text { Hatten Sie Interesse, im } \\
\text { Format der multimodalen } \\
\text { Interaktion zu arbeiten? }\end{array}$ & & & & & \\
\hline 4 & $\begin{array}{l}\text { Wie beurteilen Sie die } \\
\text { Entwicklung Ihrer } \\
\text { kommunikativen } \\
\text { Fremdsprachenkenntnisse } \\
\text { während des Experiments? }\end{array}$ & & & & & \\
\hline 5 & $\begin{array}{l}\text { Wie gut ist es Ihnen } \\
\text { gelungen, } \\
\text { Lernschwierigkeiten bei der } \\
\text { Beherrschung eines neuen } \\
\text { Themas zu überwinden? }\end{array}$ & & & & & \\
\hline 6 & $\begin{array}{l}\text { Wie beurteilen Sie die } \\
\text { Wirksamkeit } \\
\text { Experiments für Ihre Gruppe } \\
\text { insgesamt? }\end{array}$ & & & & & \\
\hline 7 & $\begin{array}{l}\text { Wie gut wurden die } \\
\text { unterschiedlichen } \\
\text { Wahrnehmungsweisen von } \\
\text { neuem Material kombiniert? }\end{array}$ & & & & & \\
\hline 8 & $\begin{array}{l}\text { Wie hat sich das Experiment } \\
\text { auf Ihre Aktivität und } \\
\text { Eigeninitiative beim } \\
\text { Deutschlernen ausgewirkt? }\end{array}$ & & & & & \\
\hline 9 & $\begin{array}{l}\text { Wie beurteilen Sie den Grad } \\
\text { Ihrer Beteiligung an der } \\
\text { multimodalen Interaktion? }\end{array}$ & & & & & \\
\hline 10 & $\begin{array}{ll}\text { Wie beurteilen Sie die } \\
\text { technische } & \text { Unterstützung } \\
\text { der } & \text { multimodalen } \\
\text { Interaktion? } & \end{array}$ & & & & & \\
\hline
\end{tabular}




\section{Appendix B}

Sample graphic presentation of educational material (Beispielhafte grafische Darstellung von Lehrmaterial)

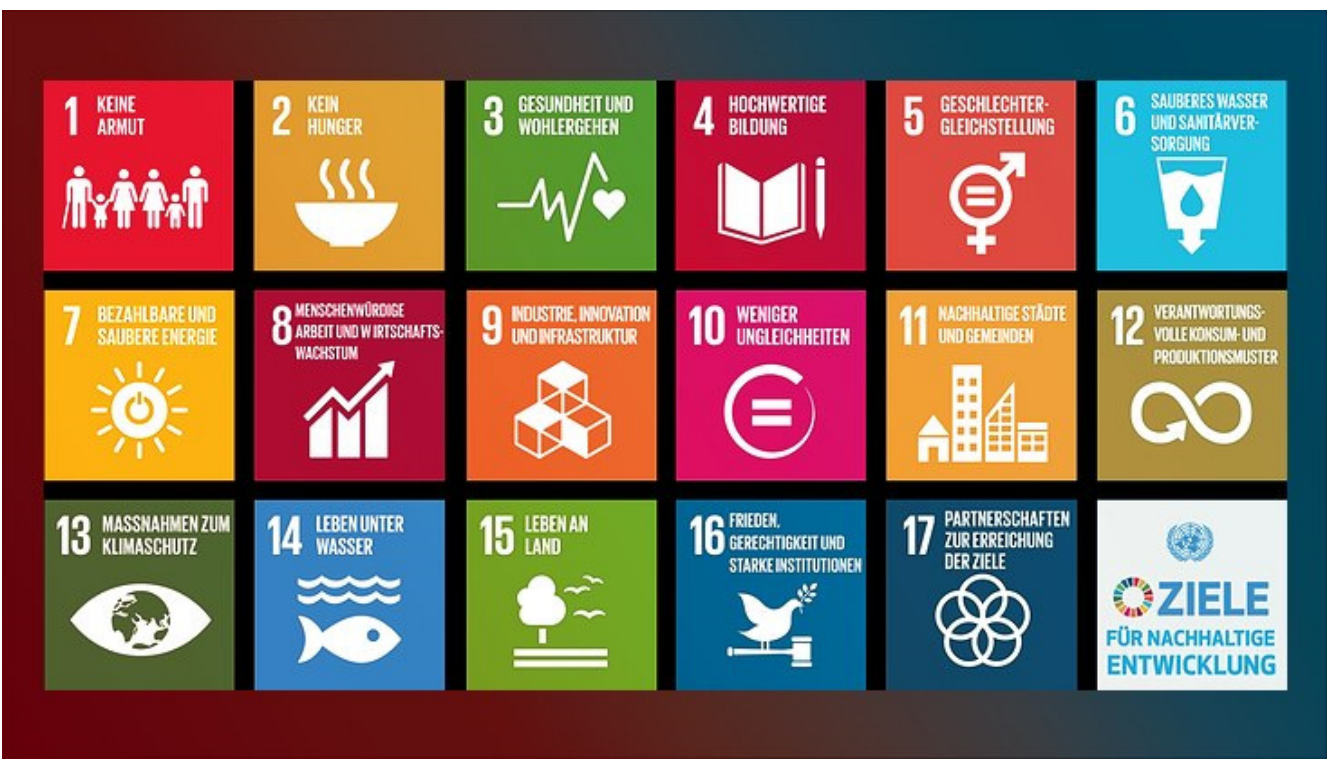

2015 LEBTEN

736 MILLIONEN

MENSCHEN IN

EXTREMER ARMUT, DAVON

413 MILLIONEN

IN AFRIKA SÜDLICH

DER SAHARA

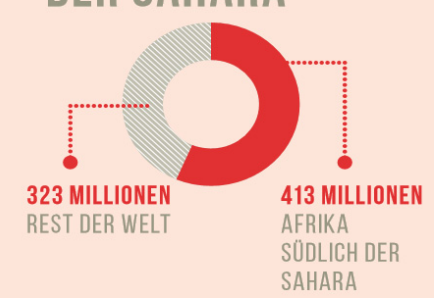

Armut ist gefährlicher als Adipositas oder Bluthochdruck

Verkürzung der Lebensdauer abhängig von folgenden Faktoren (in Jahren)

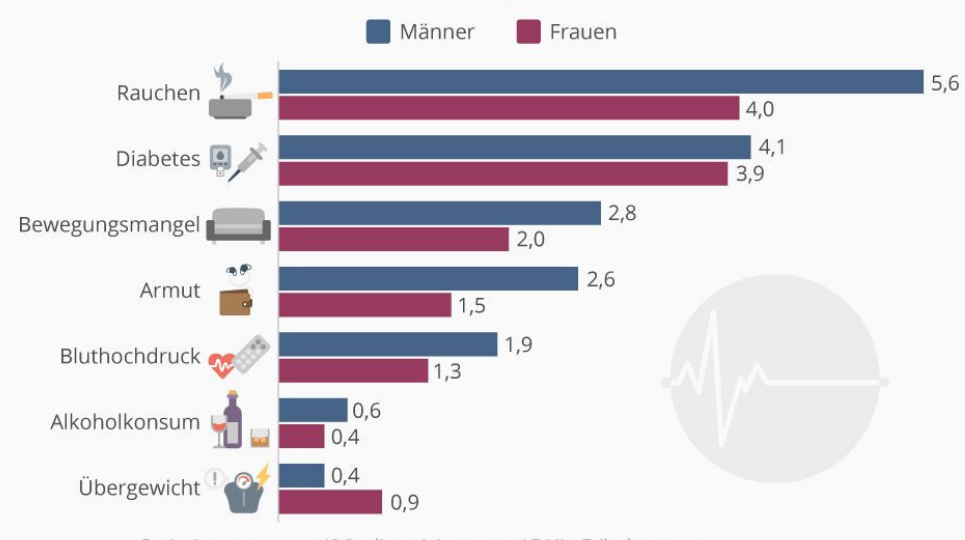

(c) (i) $\odot \begin{aligned} & \text { Basis: Auswertung von } 48 \text { Studien mit insgesamt 1,7 Mio. Teilnehmern aus } \\ & \text { Großbritannien, Frankreich, Schweiz, Portugal, Italien, USA und Australien }\end{aligned}$ Quelle: Lifepath Consortium statista

\section{Copyrights}

Copyright for this article is retained by the author(s), with first publication rights granted to the journal.

This is an open-access article distributed under the terms and conditions of the Creative Commons Attribution license (http://creativecommons.org/licenses/by/4.0/). 